\title{
APLIKASI MENGGAMBAR TEKNIK BANGUNAN DENGAN MENGGUNAKAN METODE MANUAL DAN DIGITAL
}

\author{
Shubhan AlFajri ${ }^{1}$, Irma Novrianty Nasution ${ }^{2}$ \\ ${ }^{1}$ Alumni Program Studi Diploma III Teknik Sipil, Fakultas Teknik UNIMED \\ 2Dosen Pengajar Jurusan Pendidikan Teknik Bangunan, Fakultas Teknik UNIMED \\ (irmanasution@gmail.com)
}

\begin{abstract}
ABSTRAK
Penelitian ini bertujuan untuk mengetahui tahapan-tahapan dalam menggambar teknik bangunan dengan menggunakan metode manual dan digital, serta untuk mengetahui kelebihan dan kekurangan dalam menggambar bangunan secara manual dan digital. Penelitian ini membahas tahapan-tahapan dalam menggambar teknik bangunan rumah tinggal dengan menggunakan metode manual yang menggunakan pensil dan kemudian diaplikasikan dalam bentuk digital 3D (tiga dimensi) dengan menggunakan aplikasi komputer. Aplikasi komputer yang digunakan untuk menggambar dalam bentuk 3D (tiga dimensi) cukup banyak macamnya. Meskipun banyak, maka dipilihlah aplikasi SketchUp sebagai salah satu solusi menarik untuk menggambar bangunan 3D (tiga dimensi), karena dengan menggunakan aplikasi ini proses pengerjaannya tidak terlalu sulit. Dari hasil penulisan dalam menggnelitian gambar teknik bangunan rumah tinggal dengan metode manual dan digital pada tugas akhir ini, dapat diketahui adanya kelebihan dan kekurangan dari tahap pengerjaannya masingmasing. Kelebihan dalam menggambar dengan cara manual yaitu perancang lebih leluasa mendesain dengan menggunakan pensil. Kekurangannya yaitu perancang harus menyediakan banyak duplikasi gambar sketsa agar dapat membuat alternatif gambar lainnya. Kelebihan dari menggambar dengan cara digital memiliki fasilitas duplikasi untuk kemudian dapat dimodifikasi kembali. Kekurangannya yaitu jika listrik padam proses pekerjaan yang belum disimpan tidak akan muncul kembali, kecuali memliki sistem Autosave (menyimpan sendiri) pada komputernya.
\end{abstract}

Kata Kunci : Aplikasi, Digital, Manual

\begin{abstract}
This research aims to determine the stages in building engineering drawing using manual and digital methods, as well as to know the advantages and disadvantages in building drawing manually and digitally. In this research discussed the stages in drawing technique residential buildings using the manual method using a pencil and then applied in the digital form of 3D (three dimensional) using computer applications. Computer application used to draw in 3D (three-dimensional) pretty much stuff. Although many, it was chosen as one of the SketchUp application attractive solution for drawing 3D buildings (three-dimensional), because by using this application process is not too difficult process. From the results of the drawing technique of writing residential buildings with manual and digital methods in this thesis, can be known of the advantages and disadvantages of each stage of the process. Excess in drawing by hand is the designer more flexibility to design using a pencil. The drawback is the designer should provide a lot of duplication of the drawing in order to create an alternative other images. The advantages of having a digital drawing by way of duplication of facilities can then be modified again. The drawback is if the power goes out process unsaved work will not appear again, unless the system possess Autosave (save himself) on his computer.
\end{abstract}

Keywords: Application Drawing Engineering Building Using Manual And Digital Methods. 


\section{Pendahuluan}

Gandung Purwanto (2002) dalam buku Menggambar Teknik Dasar, menjelaskan bahwa gambar teknik adalah gambar yang dibuat dengan menggunakan ketentuan caracara, ketentuan-ketentuan, aturan-aturan yang telah disepakati bersama oleh ahli-ahli teknik. Menggambar teknik merupakan suatu teknik menggambar dasar yang diajarkan mulai dari menggoreskan sepenggal garis yang sangat jelas dari benda nyata, ide atau rencana yang diusulkan untuk pembuatan atau konstruksi selanjutnya. Gambar mungkin berbentuk banyak, tetapi metode membuat gambar yang sangat jelas adalah sebuah bentuk alami dasar dari komunikasi ide-ide yang umum. Menggambar teknik memiliki fungsi sebagai media penyampaian informasi yang komunikatif karena gambar dapat di mengerti, terukur (memiliki skala), akurat (presisi tepat teknis), efektif (tepat dalam penggunaannya), serta estetik (keindahannya). Gambar teknik yang komunikatif dan lengkap (skala, notasi, legenda) tidak akan menimbulkan tafsiran yang berbeda bagi orang yang melihatnya, karena gambar yang dibuat telah mengikuti kesepakatan gambar berdasarkan standar internasional.

Pada dasarnya menggambar teknik sangat dibutuhkan disegala bidang, terutama di bidang ilmu arsitektur dan ilmu teknik sipil. Dalam bidang tersebut menggambar merupakan salah satu kemampuan dasar yang harus dimiliki, khususnya dalam menggambar bangunan. Semakin berkembangnya zaman semakin banyak pula proyek bangunan yang akan dibangun, sehingga dibutuhkan kemampuan teknik menggambar dalam era digital, seperti menggambar dalam bentuk 3D (tiga dimensi). Secara teknis pelaksanaan penggambaran lengkap tetap bisa diserahkan kepada drafter (juru gambar) yang lebih berpengalaman dan berkualitas. Menggambar teknik juga perlu didalami untuk kehidupan mendatang yang bertujuan untuk mempermudah pekerjaan dalam bidang teknik. Pada umumnya menggambar teknik dilakukan dengan menggunakan pensil ataupun rapidograph. Namun semakin berkembangnya zaman berkembang pula ilmu teknologi atau disebut juga era digital. Salah satu teknologi yang berkembang adalah perangkat lunak (software) komputer. Ditinjau dari perkembangannya, peran perangkat lunak pada komputer sangat dibutuhkan dalam berbagai bidang khususnya bidang arsitek dan teknik sipil dalam membuat gambar bangunan dan menggambar dengan menggunakan cara digital dalam menggambar teknik semakin diutamakan.

Tahap awal dalam merancang bangunan yang harus dibuat oleh perancang adalah membuat gambar sketsa. Dalam gambar sketsa perancang dapat merencanakan arah rancangan/desain dalam hal bentuk, ukuran, warna, maupun gaya arsitektur dari sebuah bangunan. Sehingga perancang dapat melakukan proses penggambaran sesuai teknik menggambar yang diinginkan. Teknik menggambar secara manual dilakukan dengan menuangkan ide-ide di atas kertas kosong yang digoreskan dengan menggunakan pensil ataupun rapido. Sedangkan teknik menggambar secara digital dilakukan dengan cara langsung merancang di komputer atau dengan cara membuat gambar sketsa manual terlebih dahulu untuk kemudian dilanjutkan di komputer. Menggambar dengan cara digital membutuhkan komputer dan aplikasi perancangan berupa perangkat lunakserta proses pemindahan data gambar manual ke komputer yang dapat dilakukan menggunakan scanner (alat pemindai) atau kamera digital dan printer (alat cetak) untuk mencetak gambar dari hasil pengerjaan. Menggambar dengan cara manual dan digital memiliki kelebihan dan kekurangan. Kelebihan menggambar dengan cara manual adalah perancang lebih leluasa mendesain dengan pensil. Dalam hal alat perancang tidak bergantung kepada listrik ataupun komputer. Kekurangan dari proses menggambar dengan cara manual adalah perancang harus menyediakan banyak duplikasi gambar sketsa agar dapat membuat alternatif gambar lainnya atau warna yang berbeda-beda, dalam hal penyimpanan menggambar manual pada kertas yang disimpan dan ditumpuk dalam waktu lama dapat rusak atau hilang. Sebaliknya menggambar dengan cara digital, kelebihannya adalah pada proses perancangan, perancang tidak perlu menyediakan kertas, alat tulis dan warna. Menggambar dengan cara digital memiliki fasilitas duplikasi untuk kemudian 
dimodifikasi dan disimpan sehingga mudah ditelusuri kembali.

Dalam pembangunan sarana jalan ada 3 hal yang perlu mendapat perhatian yang serius yaitu perencanaan, pelaksanaan dan pengawasan. Dalam hal perencanaan perkerasan harus mempertimbangkan faktorfaktor pendukungnya antara lain: faktor ekonomi, kondisi lingkungan, sifat tanah dasar, beban lalu lintas, fungsi jalan dan faktor-faktor lainnya. Hal ini dikarenakan lapisan perkerasan berfungsi untuk menerima dan menyebarkan beban lalu lintas tanpa menimbulkan kerusakan yang berarti pada konstruksi jalan, sehingga dapat memberikan keamanan dan kenyamanan selama masa pelayanan perkerasan tersebut.

Dalam menggambar dengan cara digital dilakukan dengan menggunakan perangkat lunak. Perangkat lunak merupakan bagian dari komputer sebagai sistem pendukukung untuk mempermudah pekerjaan. Perangkat lunak yang berhubungan dengan menggambar teknik cukup banyak, di antaranya adalah SketchUp. SketchUp merupakan aplikasi yang digunakan sebagai solusi menarik dalam pembuatan model obyek 3D (tiga dimensi) yang dirancang untuk arsitek, teknik sipil, pembuat film, game developer, dan sebagainya. Aplikasi ini juga dirancang lebih mudah untuk digunakan dibandingkan beberapa program aplikasi yang ada, yaitu SketchUp, AutoCad, 3ds max, ArchiCAD, dan beberapa program lainnya. Dari berbagai macam program aplikasi 3D tersebut, pada SketchUp juga memiliki fasilitas pendukung yang berfungsi sebagai pendukung proses kerja pembuatan obyek 3D, yaitu $3 D$ Warehouse (pustaka bagi para pengguna SketchUp) dan VRay for SketchUp (render engine). Selain itu aplikasi ini dapat juga disimpan dengan format Portable Network Graphics (.png) ataupun Joint Photographic Experts Group (.jpeg). Pada SketchUp juga dapat menghasilkan kualitas desain yang lebih akurat karena gambar 3D (tiga dimensi) ini juga dapat di atur skalanya sesuai yang di inginkan. Karena dengan menggunakan SketchUp lebih mudah digunakan dibandingkan perangkat lunak lainnya.

\section{Kajian Teori}

\subsection{Penjelasan Teoritis}

Menggambar teknik merupakan suatu teknik menggambar dasar yang diajarkan mulai dari menggoreskan sepenggal garis yang sangat jelas dari benda nyata, ide atau rencana yang diusulkan untuk pembuatan atau konstruksi selanjutnya. Gambar mungkin berbentuk banyak, tetapi metode membuat gambar yang sangat jelas adalah sebuah bentuk alami dasar dari komunikasi ide-ide yang umum.

Menggambar teknik memiliki fungsi sebagai media penyampaian informasi yang komunikatif karena gambar dapat di mengerti, terukur (memiliki skala), akurat (presisi tepat teknis), efektif (tepat dalam penggunaannya), serta estetik (keindahannya). Tetapi gambar teknik tidak akan menimbulkan tafsiran yang berbeda bagi orang yang melihatnya. Oleh karena itu, perlu ada tanda-tanda/patokan tertentu sebagai suatu perjanjian bersama. Patokan-patokan tersebut biasanya terdapat dalam suatu normalisasi atau standar internasional. Standar ini penting untuk dipahami oleh orang teknik, khususnya teknik sipil dan arsitektur atau orang yang akan memahami/membuat gambar teknik bangunan. Jadi, di dalam gambar teknik harus memakai tanda-tanda gambar standar dan seragam, selengkap mungkin agar dapat memberikan pengertian yang lengkap dan dimengerti oleh orang lain.

\subsection{Menggambar Teknik Bangunan}

Dalam menggambar teknik bangunan dapat dilakukan dalam bentuk 2D (dua dimensi) dan 3D (tiga dimensi). Dalam menggambar teknik bangunan harus mampu membuat gambar yang paling mendasar, yaitu:

a. Gambar Denah

b. Gambar Potongan

c. Gambar Tampak

\subsubsection{Gambar Denah}

Gambar denah adalah pandangan dari atas dengan potongan horizontal suatu bangunan setinggi $1 \mathrm{~m}$ dari ketinggian 0.00 dengan bagian atas bangunan dibuang/dihilangkan. Fungsi denah antara lain untuk menunjukkan fungsi ruang, susunan ruang, sirkulasi ruang, dimensi ruang, letak pintu dan bukaan, isi ruang, fungsi utilitas ruang (air, listrik, AC, dll.) pada denah-denah tertentu.

\subsubsection{Gambar Potongan}

Gambar potongan bangunan adalah tampak suatu bangunan yang dipotong secara 
vertikal maupun horizontal sehingga memperlihatkan isi atau bagian dalam bangunan tersebut. Fungsi potongan untuk menunjukkan Struktur bangunan, Dimensi tinggi ruang

Gambar potongan yang biasa disajikan dalam rangka melengkapi gambar-gambar rencana bangunan hanya ada tiga (tiga) jenis, yaitu :

a. Gambar potongan bangunan atau gambar irisan bangunan secara keseluruhan.

b. Gambar potongan ruang-ruang yang diperlukan atau gambar irisan ruangruang.

c. Gambar potongan detail atau gambar detail.

\subsubsection{Gambar Tampak}

Gambar tampak adalah gambar wujud luar bangunan yang dilihat secara dua dimensi dari sisi muka maupun samping. Fungsi gambar tampak antara lain untuk menunjukkan dimensi bangunan, proporsi, gaya arsitektur, warna \& material, estetika

\subsection{Alat dan Bahan Menggambar Teknik}

\subsubsection{Menggambar Manual}

Dalam menggambar dengan cara manual diperlukan beberapa alat yang digunakan untuk mempermudah proses menggambar, yaitu:
a. Pensil Gambar (Pensil Biasa dan Pensil Mekanik)
b. Rapidograph / Pena Teknik
c. Jangka
d. Penggaris T (Mistar Gambar) dan Penggaris Segitiga
e. Penghapus dan Alat Pelindung Penghapus
f. Sablon dan mal curva
g. Meja Gambar
h. Mesin Gambar

Bahan yang diperlukan dalam menggambar dengan cara manual hanya membutuhkan kertas. Jenis kertas gambar yang digunakan dalam menggambar manual adalah jenis kertas yang bertekstur, tidak licin dan tidak mengilat. Hal ini bertujuan agar mendapatkan hasil gambar yang optimal.

\subsubsection{Menggambar Digital}

Dalam menggambar dengan cara digital hanya memerlukan alat berupa perangkat keras (hardware) yang bernama komputer dan alat pendukung lainnya seperti, Printer dan Plotter

Dalam menggambar dengan cara digital diperlukan sebuah program aplikasi yang berupa perangkat lunak (software). Perangkat lunak adalah kumpulan beberapa perintah yang dieksekusi oleh mesin komuter dalam menjalankan pekerjaanya. Perangkat lunak ini merupakan catatan bagi mesin komputer untuk menyimpan perintah, maupun dokumen serta arsip lainnya. Fungsi perangkat lunak adalah mengidentifikasi program, menyiapkan aplikasi program agar tata kerja seluruh peralatan terkontrol, mengatur dan membuat pekerjaan lebih efisien.

\subsection{Teknik Menggambar}

Teknik menggambar yang paling mendasar adalah membuat garis. Garis menentukan batas-batas ruang, membentuk isi, menghasilkan susunan dan menghubungkan bentuk abjad dan angka. Garis kerja dalam gambar rencana dan potongan harus tajam dan padat, dengan lebar yang sama dan nilai yang tetap. Ada 5 (lima) jenis garis dasar :

a. Titik-titik (-................)

b. Garis pendek (-------- )

c. Garis panjang $(-----)$

d. Garis ekstra panjang $(-\square-\square$ )

e. Garis menerus (

Pada teknik menggambar juga ada 5 (lima) macam lebar garis dasar :

a. Ekstra tebal ( )

b. Tebal ( )

c. Medium $\longleftarrow$ )

d. Tipis (-

e. Ekstra tipis (— )

Semua garis harus dimulai dan diakhiri dengan tegas, ujungnya harus bertemu, selalu mempunyai kaitan yang logis dengan garisgaris lainnya dari permulaan sampai akhir.

Pada teknik menggambar juga diperlukan obyek pendukung yang digunakan untuk membaca gambar teknik, yaitu :

a. Skala

Digunakan untuk mengecilkan atau memperbesar ukuran penyajian obyek gambar, agar obyek gambar dapat dituangkan diatas kertas gambar dalam keadaan mudah dimengerti. Pemakaian skala pada gambar berarti menyajikan perbandingan nyata dari benda. Skala kecil biasanya akan sedikit memperlihatkan 
dengan jelas detail yang akan di kehendaki secara penuh.

b. Legenda

Legenda yaitu sistem penggambaran untuk memperlihatkan jenis bahan, struktur/susunan yang berlaku umum dan dapat dimengerti oleh semua pihak yang berhubungan dengan pekerjaan penggambaran tersebut.

c. Notasi material

Notasi material yaitu notasi yang dibuat pada gambar untuk menjelaskan bagianbagian gambar yang lain pada lembar yang sama atau lembar lainnya, seperti menjelaskan tempat dan jenis konstruksi yang harus dibuat pada saat pekerjaan dilaksanakan.

\subsection{Teknik Menggambar Manual}

\subsubsection{Teknik Menggambar Menggunakan} Pensil

Untuk menggambar teknik dapat menggunakan pensil biasa dan pensil mekanik. Pada umumnya pensil biasa yang digunakan adalah pensil dengan kekerasan sedang, yaitu dengan kekerasan $2 \mathrm{H}$ atau $\mathrm{H}$ dan harus runcing. Sedangkan pensil mekanik tidak perlu di runcingkan, karena pensil ini lebih praktis hanya mengisi ulang dengan berbagai ukuran ujung pensil.

Teknik menggambar dengan menggunakan pensil yaitu kedudukan pensil pada waktu digunakan untuk menarik garis harus dimiringkan ke kanan dengan sudut $60^{\circ}$ $80^{\circ}$ dan tegak lurus terhadap arah atas bawah kertas gambar. Jika menggunakan penggaris jangan menarik garis sampai keujung penggaris, karena akan menyebabkan penggaris menjadi kotor dan garis akan tampak kurang tegas. Jika menggunakan jangka ujung pensil harus diruncingkan supaya garis-garis yang dihasilkan akan tajam.

Kualitas garis yang dihasilkan dengan menggunakan pensil ada 3 (tiga) karakteristik, yaitu :

a. Kepadatan atau tekanan garis,

b. Ukuran lebar garis, dan

c. Konsistensi garis.

\subsubsection{Teknik Menggambar Menggunakan Raphido}

Teknik menggambar dengan menggunakan rapido yaitu sebaiknya posisi mata rapido ditempelkan saja pada kertas pada saat menarik garis, jangan ditekan, kemudian ditarik dengan kemiringan antara $60^{\circ}-80^{\circ}$ dari arah kiri ke kanan. Disamping itu jangan menarik garis dari atas ke bawah.

\subsection{Teknik Menggambar Digital}

Teknik menggambar secara digital dilakukan menggunakan bantuan aplikasi komputer yang berupa perangkat lunak (software). Dalam bidang arsitektur dan teknik sipil menggambar teknik bangunan menggunakan perangkat lunak sangat diutamakan, khususnya menggambar bentuk 3D (tiga dimensi). Perangkat lunak yang digunakan untuk menggambar teknik dalam bentuk 3D cukup banyak macamnya, antara lain yaitu AutoCAD, ArchiCAD, 3D Max, SketchUp, dan sebagainya.

Dari salah satu perangkat lunak yang akan digunakan, diawali dengan proses pengiinstall-an terlebih dahulu kedalam komputer. Setelah selesai proses instalasi, aplikasi tersebut langsung dapat dicoba. Aplikasi menggambar tersebut dapat digunakan mulai dengan mengklik salah satu tools (alat-alat) yang sudah tersedia, serta dapat mengatur pencahayaan, mengubah sudut pandang, dan mengubah tampilan obyek tersebut.

\subsection{Metode Menggambar Teknik}

\subsubsection{Metode Menggambar Manual}

Dalam menggambar teknik bangunan dengan cara manual ini ada beberapa tahapantahapan perencanaan, yaitu :

a. Gambar denah

Saat membuat gambar denah, harus memperhatikan segala ketentuannya, antara lain:

- Langkah pertama adalah gambarkan garisgaris utama kerangka dan garis-garis pembantu lain yang menentukan letak unsur-unsur struktur dan dinding.

- Kemudian gambarkan dinding-dinding utamanya dan unsur-unsur struktur lainnya seperti kolom-kolom dan tiangtiang yang diberi ukuran yang sederhana.

- Selanjutnya gambarkan unsur utama lainnya yang terpasang seperti jendela, pintu, tangga, dan yang lainnya di gambar berikutnya.

- Akhirnya detail-detail lain seperti perlengkapan-perlengkpan lain, pintu- 
pintu, arah pembukaan daun pintu dan lebar anak anak tangga.

b. Gambar potongan

Saat membuat gambar potongan, kita harus memperhatikan segala ketentuannya, antara lain:

- Langkah awal adalah menggambarkan dengan lengkap dari batas tampak yang terpotong sampai ke ruang-ruang di dalam bangunan secara vertikal dengan pandangan horizontal (memanjang dan melintang).

- Bagian yang dipotong dalam bangunan ditunjukkan dengan garis terputus-putus yang menunjukkan letak dan arah pandangan dalam potongan pada denah setiap lantai bangunan.

- Potongan diletakkan pada bagian-bagian yang memerlukan penjelasan lebih rinci yang dapat menunjukkan prinsip bangunan secara keseluruhan.

- Bagian yang terpotong digaris tebal dengan notasi material bila merupakan gambar kerja.

- Skala yang digunakan untuk menggambar potongan dapat disesuaikan dengan kebutuhan.

c. Gambar tampak

Dalam menggambar tampak bangunan harus mengikuti tahapan berikut :

- Langkah awal adalah membuat garis yang sejajar dari bidang datar dengan bidang gambar dan tegak lurus terhadap garis pandangan.

- Membuat bagian-bagian bangunan yang terlihat dari luar, seperti pintu dan jendela.

- Gunakan ketebalan garis yang berbedabeda untuk menunjukkan kesan jarak dari bidang-bidang yang ada.

- Gambar tampak tidak perlu dilengkapi dengan ukuran baik lebar, panjang maupun tinggi bangunan, tetapi harus digambar dengan semenarik mungkin lengkap dengan dekorasi sesuai dengan perencanaannya.

- Skala yang digunakan untuk menggambar potongan dapat disesuaikan dengan kebutuhan.

\subsubsection{Metode Menggambar Digital Menggunakan Aplikasi SketchUp}

Aplikasi ini digunakan untuk menggambar dalam bentuk 3D. Cara kerjanya tidak terlalu sulit, karena hanya memanfaatkan tools (alat kerja) yang sudah tersedia.

a. Gambar denah

Membuat gambar denah dimulai dalam bentuk 2D (dua dimensi) dan diawali dengan membuat dinding.

- Aktifkan toolbar views dengan mengklik menu Views lalu klik ikon Top untuk melihat dari atas. Selanjutnya klik Rectangle di toolsuntuk membuat kotak sembarang.

- Masukan ukurannya di Dimensions sesuai yang diinginkan, lalu enter.

- Kemudian klik Offset untuk menduplikasikan garis sebelumnya untuk membuat dinding.

- Selanjutnya klik select untuk mem-block atau menyeleksi garis dan klik move untuk mengcopy garis-garis secara horizontal dan vertikal agar membentuk ruangan-ruangan yang di inginkan.

- Klik Iso di Tools View, sehingga denahnya berubah jadi pandangan Perspektif.

- Ubahlah gambar denah 2D di atas menjadi gambar 3D dengan menggunakan Push/Pull.

b. Gambar potongan

Tahapan membuat potongan pada SketchUp menggunakan ikon Section Tool (i)े, yaitu tool yang digunakan untuk membuat potongan dari suatu objek.

- Klik Section Tool pada obyek tersebut sehingga menyesuaikan dengan posisi dari dinding yang akan di potong. Klik pada bagian yang akan di potong.

- Klik move tool dan geser kearah dalam sesuai yang di inginkan untuk menunjukkan bagian potongan pada objek.

- Pastikan Section tool tetap aktif dan Gunakan edit > option section plan > aline tool section view untuk melihat potongan tersebut, jika tidak ingin ada plan dapat memilih pada view check/uncheck untuk menampilkan atau tidak menampilkan gaet potongan tersebut.

- Kemudian pada kamera pun dapat melihat perspektif atau parallel projection. Jika menggunakan parallel projection gambar akan terlihat pada kondisi tepat tanpa perspektif artinya tepat tampak pada depannya.

\section{c. Gambar tampak}

Jika proses menggambar telah selesai, kemudian dilanjutkan untuk membuat tampak. Dalam aplikasi ini membuat tampak hanya menggunakan tools yang telah disediakan pada bagian standard view. Toolbar ini mempermudah 
untuk melihat obyek dari sudut pandang yang diinginkan, yaitu :

- Iso $A^{3}$, berfungsi memperlihatkan obyek dalam bentuk perspektif.

- Top [1], berfungsi memperlihatkan obyek dalam view top atau tampak atas.

- Front $\widehat{\Lambda}$, berfungsi memperlihatkan obyek dalam view front atau tampak depan.

- Right $\square$ berfungsi memperlihatkan obyjek dalam view right atau tampak samping kanan.

- Left $\square$ berfungsi memperlihatkan obyek dalam view left atau tampak kiri.

- Back $\bar{\triangle}$ berfungsi memperlihatkan obyek dalam view back atau tampak belakang.

\subsubsection{Metode Menggambar Digital Menggunakan} Aplikasi AutoCAD 2007

Menggambar teknik dengan cara digital juga dapat dilakukan dengan menggunakan aplikasi AutoCAD 2007. Cara kerja aplikasi ini hanya memanfaatkan tools (alat kerja) yang sudah tersedia. Berikut adalah cara menggambar denah, potongan, dan tampak dengan menggunakan AutoCad 2007 dalam bentuk 3D (tiga dimensi).

\section{a. Gambar denah}

Membuat gambar denah dimulai dalam bentuk 2D (dua dimensi) dan diawali dengan membuat dinding.

- Klik ikon Top untuk melihat dari atas. Selanjutnya klik line di tools dan klik sembarang di lembar kerja untuk garis secara vertikal dan horizontal.

- Masukan ukurannya ketika garis akan dibuat sesuai keinginan lalu tekan enter.

- Kemudian klik Offset di tools untuk menduplikasikan garis sebelumnya untuk membuat dinding.

- Selanjutnya block atau seleksi garis dan klik move untuk meng-copy garis-garis secara horizontal dan vertikal agar membentuk ruangan-ruangan yang di inginkan.

- Klik Iso di Tools 3D View, sehingga denahnya berubah jadi pandangan Perspektif.

- Ubahlah gambar denah 2D di atas menjadi gambar 3D dengan menggunakan tools box.

b. Gambar Potongan

Tahapan membuat potongan pada Autocad 2007 diawalai dari pembuatan denah potongan baik secara melintang maupun memanjang.

- Buat duplikat gambar denah bangunan yang sudah di gambar sebelumnya dengan menyeleksi seluruh gambar denah tersebut, lalu klik ikon copy dan geser gambar tersebut ke sembarang tempat sehingga menghasilkan gambar denah yang baru.

- Kemudian buat garis potongan pada denah tersebut untuk menentukan potongan bangunan secara melintang dan memanjang.

- Klik ikon box untuk membentuk dinding bangunan menjadi bentuk 3D (tiga dimensi) dan dilanjutkan memasang gambar pintu, jendela dan atap.

c. Gambar tampak

Dalam aplikasi ini membuat tampak hanya menggunakan tools yang telah disediakan pada bagian menu view 3D. Toolbar ini mempermudah untuk melihat obyek dari sudut pandar $\stackrel{n}{ } \times$ g diinginkan, yaitu :

- Iso berfungsi memperlihatkan obyek dalam bentuk perspektif.

- Top $\nabla$ berfungsi memperlihatkan obyek dalam view top atau tampak atas.

- Front $\square$ berfungsi memperlihatkan obyek dalam view front atau tampak depan.

- Right $\$$ berfungsi memperlihatkan obyjek dalam view right atau tampak samping kanan.

- Left berfungsi memperlihatkan obyek dalam view left atau tampak kiri.

- Back berfungsi memperlihatkan obyek dalam view back atau tampak belakang.

\section{Aplikasi Menggambar Teknik Bangunan Dengan Metode Manual dan Digital}

\subsection{Aplikasi Menggambar Teknik Bangunan}

Dalam pembahasan ini akan membahas mengenai tahapan-tahapan dalam pembuatan gambar denah, potongan, dan tampak pada bangunan. Bangunan yang digambar adalah rumah tinggal dengan ukuran bangunan $9 \times 13$ $\mathrm{m}\left(117 \mathrm{~m}^{2}\right)$. Proses menggambar dilakukan dengan cara manual dalam bentuk 2D (dua dimensi) dan kemudian dilanjutkan dengan cara digital dalam bentuk 3D (tiga dimensi).

\subsubsection{Tahap Menggambar Bangunan dengan \\ Metode Manual}

Tahapan dalam menggambar bangunan rumah tinggal dengan cara manual dilakukan menggunakan pensil dan kertas A4 (297 x 210 $\mathrm{mm}$ ) dalam bentuk 2D (dua dimensi).

\section{a. Menggambar denah}

- Gunakan kertas putih berukuran 297 x $210 \mathrm{~mm}$ (A4). Kemudian buatlah garis 
tepi pada kertas dengan jarak $1,5 \mathrm{~cm}$. Gunakan pensil yang bermata runcing dan bantuan penggaris untuk membuat ukuran denah dan membuat garis secara lurus.

- Buat persegi panjang diawali dengan memberikan titik sebagai patokan dan diukur dengan bantuan penggaris untuk menentukan jaraknya, lalu diberi garis dari titik ke titik tersebut sampai membentuk persegi panjang dengan menggunakan pensil yang ketebalnnya $\mathrm{H}$.

- Kemudian membentuk susunan ruang, sirkulasi ruang, dimensi ruang, letak pintu dan bukaan dengan cara membuat garis-garis secara horizontal ataupun vertikal dan memberikan titik-titik terlebih dahulu pada setiap garis denah tersebut dengan jarak-jarak yang ditentukan.

- Hapus garis-garis yang tidak diperlukan dengan menggunakan penghapus, agar denah yang sudah dikerjakan akan terbentuk dengan sempurna dengan susunan ruangan dan dimensi ruangan serta letak pintu dan bukaan.

- Dari menggambar denah juga dapat dilanjutkan menggambar denah pintu dan jendela dan denah atap.

\section{b. Menggambar potongan}

- Gunakan kertas dengan ukuran yang sama untuk membuat gambar potongan bangunan secara vertikal dalam pandangan horizontal (melintang dan memanjang). Satukan kertas gambar denah yang sudah dibuat ke kertas yang akan dibuat gambar potongan tersebut dengan jarak tertentu.

- Untuk membuat gambar potongan bangunan diawali dengan menarik garis sepanjang mungkin dari setiap sudut bangunan dan dari materialmaterial yang terlihat didalam bangunan pada gambar denah dan berikan garis secara horizontal sebagai titik 0.00 pada bangunan dan buat garis secara horizontal kedua dengan jarak ketinggian $3.70 \mathrm{~cm}$ dari titik 0.00 tersebut.

- Kemudian buat garis duplikat dari garis sebelumnya sesuai dengan ukuran dan jaraknyanya agar membentuk bagian bangunan yang terpotong. Selanjutnya masukkan notasi material yang digunakan pada bagian bangunan yang dipotong seperti pada kolom-kolom dinding dan material pintu dan jendela yang terlihat pada bagian dalam bangunan.

- Pada bagian yang terpotong tersebut diberigaris sesuai dengan ketebalannya untuk mengetahui jarak pada bagian luar dan dalam bangunan yang terlihat dan pada notasi material tersebut.

- Selanjutnya buat garis pada bagian atas bangunan dengan sudut $35^{\circ}$ untuk membuat potongan pada bagian atap.

- Terakhir adalah menghapus garis-garis bantu yang tidak digunakan.

\section{c. Menggambar tampak}

- Gunakan kertas dengan ukuran yang sama untuk membuat tampak-tampak dari setiap sisi bangunan. Satukan kertas gambar denah yang sudah dibuat ke kertas yang akan dibuat tampak bangunan tersebut dengan jarak tertentu.

- Untuk membuat tampak depan, belakang, samping kiri, dan samping kanan, satukan kertas gambar denah yang sudah dibuat dengan posisi yang sesuai ke kertas kosong yang akan dibuat tampak secara bergantian.

- Kemudian tarik garis dari setiap sudutsudut yang ada pada denah. Selanjutnya memberi garis horizontal sebagai titik 0.0, lalu bentuk bagian tampak tersebut sesuai dengan ketinggian bangunan.

- Selanjutnya membuat material pintu dan jendela, serta bagian material lainnya yang terlihat.

- Tampak pada bagian atap dibuat dengan menarik garis $35^{0}$ dari sudut luar bagian atap.

\subsubsection{Tahap Menggambar Bangunan dengan Metode Digital Menggunakan Aplikasi Sketchup \\ Tahapan dalam menggambar bangunan} rumah tinggal dengan cara digital dilakukan menggunakan komputer dan perangkat lunak (software) SketchUp dalam bentuk 3D (dua dimensi).

\section{a. Menggambar denah}


- Klik ikon view Top untuk mempermudah membuat gambar denah dalam bentuk 2D (dua dimensi).

- Klik ikon Ractangle (R) untuk menggambar sebuah persegi panjang dengan ketik ukuran 9000, 13000 dan enter. Kemudian block denah tersebut lalu klik kanan dan pilih Reverse Faces agar menjadi warna putih sebagai warna dasar.

- Selanjutnya klik ikon offset dan klik pada garis persegi panjang tersebut dan geser ke arah dalamdengan ketik ukuran 150 dan enter agar membentuk garis duplikat sebagai bentuk dinding.

- Perbesar tampilan obyek dengan menggunakan zoom atau scroll mouse. Klik ikon select untuk menyeleksi garis yang horizontal ataupun vertikal. Kemudian copy garis tersebut dengan klik ikon Move dan tekan tombol Ctrl pada keyboard satu kali agar mode pengkopian tersebut aktif. Geser garis yang akan di copy sesuai dengan ukuran. Lakukan secara berulang dari bagian garis yang horizontal ataupun vertikal agar membentuk sebuah denah dan ruangan yang belum sempurna.

- Klik ikon erase dan klik pada garis-garis yang tidak digunakan agar terhapus dan membentuk ruangan-ruangan agar denah kelihatan sempurna.

- Untuk membentuk dinding putar titik pandang dengan menggunakan ikon orbit. Kemudian klik ikon push/pull dan klik pada bagian dinding lalu geser ke atas dengan ketik 4000 dan enter.

b. Menggambar potongan

- Dekatkan obyek dari tampak depan untuk membuat potongan secara melintang dengan menggunakan zoom atau scroll mouse.

- Selanjutnya klik Section Tool lalu klik pada obyek tersebut sehingga menyesuaikan dengan posisi dari dinding yang akan di potong. Kemudian akan terlihat sebuah potongan yang disesuaikan dari arah potongan yang di tentukan.

- Klik move tool dan geser kearah dalam sesuai yang di inginkan untuk menunjukkan bagian potongan pada objek secara melintang.
- $\quad$ Begitu juga dengan membuat potongan secara memanjang, dekatkan obyek dari tampak samping untuk membuat potongan secara melintang dengan menggunakan zoom atau scroll mouse.

- $\quad$ Selanjutnya klik Section Tool lalu klik pada obyek tersebut sehingga menyesuaikan dengan posisi dari dinding yang akan di potong. Kemudian akan terlihat sebuah potongan yang disesuaikan dari arah potongan yang di tentukan.

- Klik move tool dan geser kearah dalam sesuai yang di inginkan untuk menunjukkan bagian potongan pada obyek secara melintang.

- Pastikan Section tool tetap aktif dan gunakan edit > option section plan > aline tool section view untuk melihat potongan tersebut, jika tidak ingin ada plan dapat memilih pada view check/uncheck untuk menampilkan atau tidak menampilkan pemandu potongan tersebut.

\section{c. Menggambar tampak}

- View Iso (Tampak perspektif)

Klik ikon Iso yang berfungsi memperlihatkan obyek dalam bentuk perspektif. Lalu gambar akan terlihat perspektif secara automatis.

- View Top (Tampak Atas)

Klik ikon Top [1 yang berfungsi memperlihatkan obyek dalam view top atau tampak atas. Dengan automatis gambar akan terlihat pada bagian atas bangunan atau bagian atap.

- View Front (Tampa ${ }^{1}$ Klik ikon Front yang berfungsi memperlihatkan obyek dalam view front atau tampak depan.

- View Right (Tampak Belakang) Klik ikon Right $\square$ yang berfungsi memperlihatkan obyek dalam view right atau tampak samping kanan.

- View Right (Tampak Kiri)

Klik ikon Left $\square$ yang berfungsi memperlihatkan obyek dalam view left atau tampak kiri.

- View Back (Tampak Rolakang) Klik ikon Back $\searrow$ yang berfungsi memperlihatkan obyek dalam view back atau tampak belakang. 
3.1.3 Tahap Menggambar Bangunan dengan Metode Digital Menggunakan Aplikasi AutoCAD 2007

a. Menggambar denah

- Klik ikon line dan klik sembarang di lembar kerja untuk garis secara vertikal dan horizontal.

- Masukan ukurannya ketika garis akan dibuat secara vertikal dengan ketik 1300 dan enter, lanjut dengan garis horizontal dengan ketik 900 dan enter. Dikerjakan sampai membentuk persegi panjang.

- Kemudian klik salah satu garis dan klik Offset, lalu klik pada garis sebelumnya dan geser ke salahsatu sisi dengan ketik $15 \mathrm{~cm}$ untuk menduplikasikan garis tersebut untuk membuat dinding.

- Kemudian block atau seleksi garis dan klik copy untuk menduplikasikan garisgaris secara horizontal dan vertikal agar membentuk ruangan-ruangan yang di inginkan.

- Untuk membuat 3D (tiga dimensi) dimulai dengan klik menubar viewports, kemudian pilih ikon display viewports dialog sehingga muncul jendela viewports dan klik menu new viewports lalu pilih Three: Left lalu OK/Enter sehingga jendela kerja menjadi 3 bagian.

- Dari pekerjaan sebelumnya dilanjutkan untuk membuat dinding dalam bentuk 3D (tiga dimensi). Kemudian klik ikon box pada menu modelling. Selanjutnya klik pada denah yang akan dibuat dinding dan tarik ke atas dengan ketik $400 \mathrm{~cm}$.

b Menggambar potongan

- Sesuaikan dengan garis potongan pada yang sudah digambar pada denah sebelumnya.

- Kemudian klik ikon box untuk membuat dinding dan geser kursor kearah atas dengan ketik 400, enter. Selanjutnya letakkan plafond, dan atap yang sudah dikerjakan pada pekerjaan sebelumnya sehingga membentuk potongan melintang atau potongan AA dan potongan memanjang atau potongan B-B.

c.Menggambar tampak

- View Iso (Tampak perspektif) Klik ikon Iso yang berfungsi memperlihatkan obyek dalam bentuk perspektif. Lalu gambar akan terlihat perspektif secara automatis.

- View Top (Tampak $\Delta$ tas)

Klik ikon Top $\square$ yang berfungsi memperlihatkan obyek dalam view top atau tampak atas. Dengan automatis gambar akan terlihat pada bagian atas bangunan atau bagian atap.

- View Front (Tampak Depan) Klik ikon Front 1 yang berfungsi memperlihatkan obyek dalam view front atau tampak depan.

- View Right (Tampak Kanan)

Klik ikon Right $\square$ yang berfungsi memperlihatkan obyek dalam view right atau tampak samping kanan.

- View Left (Tampak Kiri)

Klik ikon Left DJ yang berfungsi memperlihatkan obyek dalam view left atau tampak kiri.

- View Back (Tampak Relakang)

Klik ikon Back yang berfungsi memperlihatkan obyek dalam view back atau tampak belakang

\section{Kesimpulan dan Saran}

\subsection{Kesimpulan}

a. Tahapan-tahapan dalam menggambar denah, potongan, dan tampak dengan metode manual dilakukan menggunakan bantuan pensil, raphido, penggaris dan penghapus yang dimulai dari pemberian titik-titik sebagai patokan untuk menarik garis-garis utama dan garis duplikat secara vertikal dan horizontal sampai membentuk sebuah gambar yang diinginkan, membuat notasi material, dan menghapus bagian gambar yang tidak diperlukan sehingga gambar terlihat sempurna. Sedangkan dengan metode digital tahapan pengerjaannya dilakukan dengan bantuan aplikasi komputer yang bernama SketchUp dan dimulai dari membuat garis dan menggandakannya dengan cara meng-copy secara vertikal dan horizontal, menghapus bagian gambar yang tidak diinginkan, dan menarik bagian-bagian gambar sampai membantuk 3D (tiga dimensi) serta menambahkan notasi material yang dibutuhkan, semua itu dilakukan dengan cara mengklik ikon-ikon yang sudah disediakan pada aplikasi tersebut. 
b. Menciptakan sebuah gambar bangunan yang dilakukan secara digital dalam bentuk 3D (tiga dimensi) dibuat dengan menggunakan aplikasi SketchUp. Aplikasi ini digunakan sebagai solusi untuk mendisain apapun dalam bentuk 3D (tiga dimensi) terutama dalam menggambar sebuah bangunan dengan sangat mudah. Apabila terus ditekuni dapat menciptakan peluang kerja yang besar.

c. Adanya kelebihan dalam menggambar dengan cara manual yaitu perancang lebih leluasa mendesain dengan pensil dan tidak memerlukan komputer. Kekurangannya yaitu perancang harus menyediakan banyak duplikasi gambar sketsa agar dapat membuat alternatif gambar lainnya. Kelebihan dari menggambar dengan cara digital memiliki fasilitas duplikasi untuk kemudian dapat dimodifikasi kembali. Kekurangannya yaitu jika listrik padam proses pekerjaan yang belum disimpan tidak akan muncul kembali, kecuali memliki sistem Autosave (menyimpan sendiri) pada komputernya.

\subsection{Saran}

a. Dalam menggambar sebuah bangunan baik secara manual ataupun digital, sebaiknya harus menguasai teknik-teknik dalam menggambar agar dapat menciptakan proses pengerjaan yang singkat dan cepat, serta dapat diterapkan dalam dunia kerja ataupun bisnis.

b. Dalam pengerjaan Tugas Akhir ini penulis menjumpai kesulitan dalam mencari refrensi yang berkaitan dengan materi, sebaiknya perpustakaan menyediakan buku-buku yang berkenaan dengan jurusan Pendidikan Teknik Bangunan dan Teknik Sipil.

c. Mendisain atau menggambar dengan metode digital menggunakan SketchUp merupakan suatu karya seni yang bernilai, sebaiknya menggambar dengan metode digital menggunakan SketchUp ini dapat dijadikan sebagai materi tambahan di perkuliahan jurusan Pendidikan Teknik Bangunan dan Teknik Sipil, agar mahasiswa/i yang akan datang dapat lebih berkembang dalam menguasai teknik dalam menggambar bangunan.

\section{Daftar Pustaka}

Asla, Grant W. Reid. 2001. Grafik Lansekap. Jakarta : Erlangga

Chandra, Handi. 2012. SketchUp 8 untuk Eksterior Realistik. Palembang : Maxikom

Ching, Frank. 1992. Grafik Arsitektur, Edisi Kedua. Jakarta : Erlangga

Hadiyanto, Ahmad. 2004. Modul Gambar Dasar Teknik, Jakarta

Han, J. Oei Tek. 1987. Teknik Menggambar Dekor Dalam Gambar Interior. Yogyakarta : Kanisius

Purwanto, Gandung. 2002. Menggambar Teknik Dasar: Yogyakarta : Kanisius

Soepadmo, Gatot. 2012. Panduan Mudah Merancang Bangunan. Jakarta : Griya Kreasi

Syaputra, Aditia. 2012. Mahir Sekejap Desain Arsitektur dengan Google SketchUp. Yogyakarta : MediaKom

http:/ / faizalnabillah.blogspot.com/2012/05/caramembuat-denah-rumah-yang-baik.html

http://muhammadyahyasblog.blogspot.com/2 011/11/gambar-teknik.html

http://saidarchiteck.blogspot.com/2012/08/pengerti an-denah-tampak-dan-potongan.html

http://kk.mercubuana.ac.id/elearning/files_m odul/12002-1-886518341461.pdf

www.awok90.files.wordpress.com/2011/04/m enggambar-bangunan-gedung-ii.pdf

www.scribd.com/doc/123482527/ModulTjahyani-Krisnanto

www.scribd.com/doc/46473577/StandarisasiMenggambar-Teknik-Untuk-Arsitek 